\section{OP-105超音波吸引装置改良型肉厚プローブの基 礎的検討}

\section{東京医科大学泌尿器科学}

並木一典, 秦野 直, 澤田 陽平, 滝澤 一晴,

田中絢子, 佐竹直哉, 竹内 尚史, 権藤立男,

濱田 理宇, 小津 兆一郎, 堀口 裕, 吉岡 邦彦,

橘 政昭

【目的】超音波吸引装置は、脂肪組織のみを破砕吸引できることか らその有用性・安全性が認められているが、十分な脂肪吸引速度 が得られないことや出血を生じることもありその性能は十分とは 言えない。我々はその原因がプローブ壁の薄さにあると考え、よ り厚いプローブ（以下改良型）を試作し、仕事効率と安全性を確 認することとした。

【方法及び結果】改良型プローブの先端肉厚を $1.5 \mathrm{~mm}$ とした（従 来型 $0.2 \mathrm{~mm}$ )。ジェネレーターはオリンパス社製ソノサージを用 いた。

実験 1) 牛脂を吸引し、従来型と改良型での脂肪吸引量を測定した。 吸引圧は $-40 \mathrm{kPa}$ 、吸引時間は 3 分。単位時間あたりの脂肪吸引量 は約 3 倍となり両者間に有意差を認めた。

実験 2）豚腎周囲および腎茥部脂肪を吸引した。改良型では小血 管を損傷することなく、脂肪が効率よく吸引できることを確認した。 実験 3）豚の腎および周囲血管を摘出し、血管壁に直接プローブ を当て出力した。血管内皮細胞の剥離などのダメージは改良型に やや広く見られたが、極端な差は無かった。

【考察】プローブ壁の薄さが血管壁に過大な力を加え断裂を生じる と考え、先端を面構造とし面全体で脂肪組織を押しつぶすことに より脂肪組織を破壊するように改めた。本実験により、改良型プ ローブは安全性を保ちつつ仕事効率を増大させることが可能と考 えられた。

\section{OP-106}

\section{ダビンチによるロボット支援前立腺全摘 手術の経験}

\section{長久保病院}

塚本 拓司, 桑原 勝孝, 大柣 英男, 長久保一朗 我々は、2009 年 9 月より Intuitive Surgical 社製 da Vinci S surgical system（以下ダビンチ）を導入し、ロボット支 援前立腺全摘術を始めた。症例は 10 月 6 日現在で 3 例。 年齢; 69,70,70。術前ステージ；いずれも T1N0M0。GS; 6 、 $6 、 7(3+4)$ 。手術時間 (分) ; $400 、 338 、 460$ 。出血量（尿 量込)；100 $\mathrm{ml} 、 140 \mathrm{ml} 、 850 \mathrm{ml}$ 3 例とわずかな経験では あるが、しかし、ダビンチが提供するハイビジョン 3D 画 像やロボット工学が応用された鉗子（エンドリスト）の優 れた操作性は特筆すべきものがある。現在は手術時間も長 く満足できるものではないが、出血量が少ない点や、前立 腺尖部や神経温存などは開腹手術より良好な視野のもとに 細かな処理が可能であり、今後も積極的に本手術を行って いきたいと考えている。総会では導入初期 6 力月の経験を もとにロボット支援前立腺全摘術につき検討を加えたいと 思う。

\section{OP-107 \\ ロボット支援腹腔鏡下前立腺全摘術の初 期経験}

\begin{abstract}
金沢大学大学院医学系研究科泌尿器科学
角野 佳史, 八重樫 洋, 三輪 聰太郎, 宮城 徹, 前田 雄司, 金谷 二郎, 北川 育秀, 小中 弘之, 溝上 敦, 高 栄哲, 並木 幹夫

Da Vinci Surgical System は、立体視野のカメラスコープ と操作性にすぐれた自由度の高い鉗子を有する手術支援口 ボットである。ロボット支援手術の中でも導入当初から行 われてきた前立腺全摘術は、現在では低侵襲手術として確 立した術式であり、欧米を中心にすでに世界中で広く行わ れている。われわれの施設では、厚労省より高度医療の認 可を受け、2009 年 3 月よりロボット支援腹腔鏡下前立腺 全摘術を開始している。2009 年 9 月末現在、同手術を 10 症例経験し、全例ロボット手術で完遂している。出血は従 来の開腹手術に比べ少なく、また術後も良好な経過をた どっていることより、導入初期としては比較的満足できる 結果と思われる。最初の症例では、手術時間 5 時間 43 分、 ロボット稼働時間 4 時間 46 分、尿道膀胱吻合時間 39 分で あったが、最近の数例は、手術時間 3 時間程度、ロボット 稼働時間 2 時間から 2 時間半、尿道膀胱吻合時間 15 分程 度と短縮してきている。さらに症例を蓄積し、当院におけ る同手術の初期経験とその結果を報告する予定である。
\end{abstract}

\section{OP-108da Vinci S - HD システムを用いた ロボット支援腹腔鏡下前立腺全摘除術 (RALP) の初期成績}

\section{藤田保健衛生大学腎泌尿器外科学1), 東京医科大学泌尿器} 科学 ${ }^{2}$

丸山 高広 ${ }^{1)}$, 白木 良一 ${ }^{1)}$, 日下 守 ${ }^{1)}$, 和志田 重人 ${ }^{1)}$, 杉山 大樹1), 石川 清仁1), 秦野 直 ${ }^{2)}$, 吉目 邦彦 ${ }^{2)}$, 橘 政昭 ${ }^{2}$, 星長 清隆 ${ }^{1)}$

【目的】腹腔鏡下前立腺全摘除術を施行していない当施設に おいて、da Vinci S - HD システムを用いたRALPを導入 したので手術成績を報告する。【対象】 2009 年 8 月から 9 月 に da Vinci S - HD システム (Intuitive Surgical Inc.) を用 いRALPを施行した 5 症例。年齢は $54-70$ (中央值 : 66) 歳。PSA 值は 5.1 - 11.2（同：8.9） ng/mL で、臨床病期 は Tlc : 1 例、T2a : 3 例、T2 b : 1 例。生検での Gleason score は $3+3=6: 4$ 例、 $3+4=7: 1$ 例。手術は全身麻酔下に 砕石位で約 25 度の頭低位にて施行した。ポートは計 6 本で、 カメラポート $(12 \mathrm{~mm}) 、 \mathrm{da}$ Vinci 用ポート $(8 \mathrm{~mm}) 3$ 本、 助手用ポート 2 本を使用した。前立腺摘除は経腹膜的順行性 に施行し、神経血管束の温存を片側で 2 例、両側で 2 例に施 行した。【結果】手術時間は 3 時間 57 分 -7 時間 12 分（同： 5 時間 47 分)、コンソール時間は 2 時間 46 分 -5 時間 40 分 (同: 4 時間 25 分)。出血量（尿込み）は $50-1200$ (同：220) $\mathrm{mL}$ 、摘出重量は $29-43$ (同:36) g。同種血輸血例は無かっ た。尿道カテーテルは術後 6-7 日で抜去し、術後 9-11日 で退院した。有害事象は 1 例で術中膀胱穿孔を認めたが、術 中に縫合閉鎖した。【結語】腹腔鏡下前立腺全摘除術を施行 していない施設においても、da Vinci システムによるロボッ 卜支援RALPの導入はスムースかつ安全に施行可能であった。 